\title{
A Review of Gated Communities in Some Hungarian Cities
}

\author{
Gábor Hegedüs' \\ Received: May 2009 | Revised: August 2009 | Accepted: August 2009
}

\begin{abstract}
Modern gated communities first appeared in post-socialist European countries after the fall of Communism. During the transition to a market economy, socio-economic differences have increased immensely across the region and the development of gated communities has brought about a new form of residential segregation.
\end{abstract}

Modern gated communities have no real antecedents in Hungary. Since the beginning of the 1990s, the spread of such communities has been rapid in and around Budapest as well as in many other smaller cities.

The largest cities in Hungary - excluding Budapest - have the special administrative status of 'City with County Rights'. Most of the cities in the study had a population over 50,000. We analysed their gated communities by identifying categories of gated developments and examining the geographical dispersion of the above-mentioned categories.

Based on the results, we concluded that the term 'gated community' is used too generally in Hungary, without consideration of the exact definitions applied in the Western world. Significant differences can be observed in the numbers and spatial distribution of gated neighbourhoods amongst the cities which were analysed. In many settlements they occur in specific spatial patterns which appear to trigger local conflicts.

Keywords: gated communities, Hungary, categorisation, geographical distribution, Cities with County Rights

\section{Introduction}

The separation of different social and ethnic communities dates back to antiquity (Blakely, Synder, 1997). Walled enclaves were not only fortresses, but also symbols of security for monarchies and other members of feudal aristocracy during antiquity and the Middle Ages. Despite the historical background, the emergence and global spread of gated communities is a relatively new phenomenon of modern urban development (Glasze, et al. (eds.), 2006, Atkinson, Blandy, (eds.) 2006). Residential complexes, most similar to the recent forms of gated communities, already existed in Europe in the 19th century - also built by private investors.

However, gated communities were rare to the 1960s and 1970s. Since then, they have become widespread in the USA, firstly in the form of retirement homes, and later they appeared both in the rural areas - in the form of the so-called 'country clubs' - and in the middle-class suburbs of the USA. There is now a proliferation of such developments through- out family suburbia and areas of high-density urban apartment complexes. Since the late 1980s, they have become ubiquitous in many areas of the US (Blakely, Synder, 1997). What is more, this explosion in numbers has become a global trend; indeed, they have become popular from Latin-America to China. Unique local factors, such as existing traditions of living in enclosed communities, the level of public safety and politics, have also contributed to their success in many places. The number of gated communities has also grown in Europe, though the numbers are still low when compared with the USA. Gated neighbourhoods first appeared in Europe in the 1980s along the Mediterranean coast of Spain and France. In the 1990s, many suburban gated communities were established in the suburbs of Madrid and Lisbon, and in GreatBritain, too. They also emerged in Vienna, Berlin, and in Central and Eastern Europe at the same time (Glasze, 2001). There is a wide range of scientific literature already available on the topic of gated communities (Blandy, et al., 2003, Glasze, et al., (eds.) 2006). 


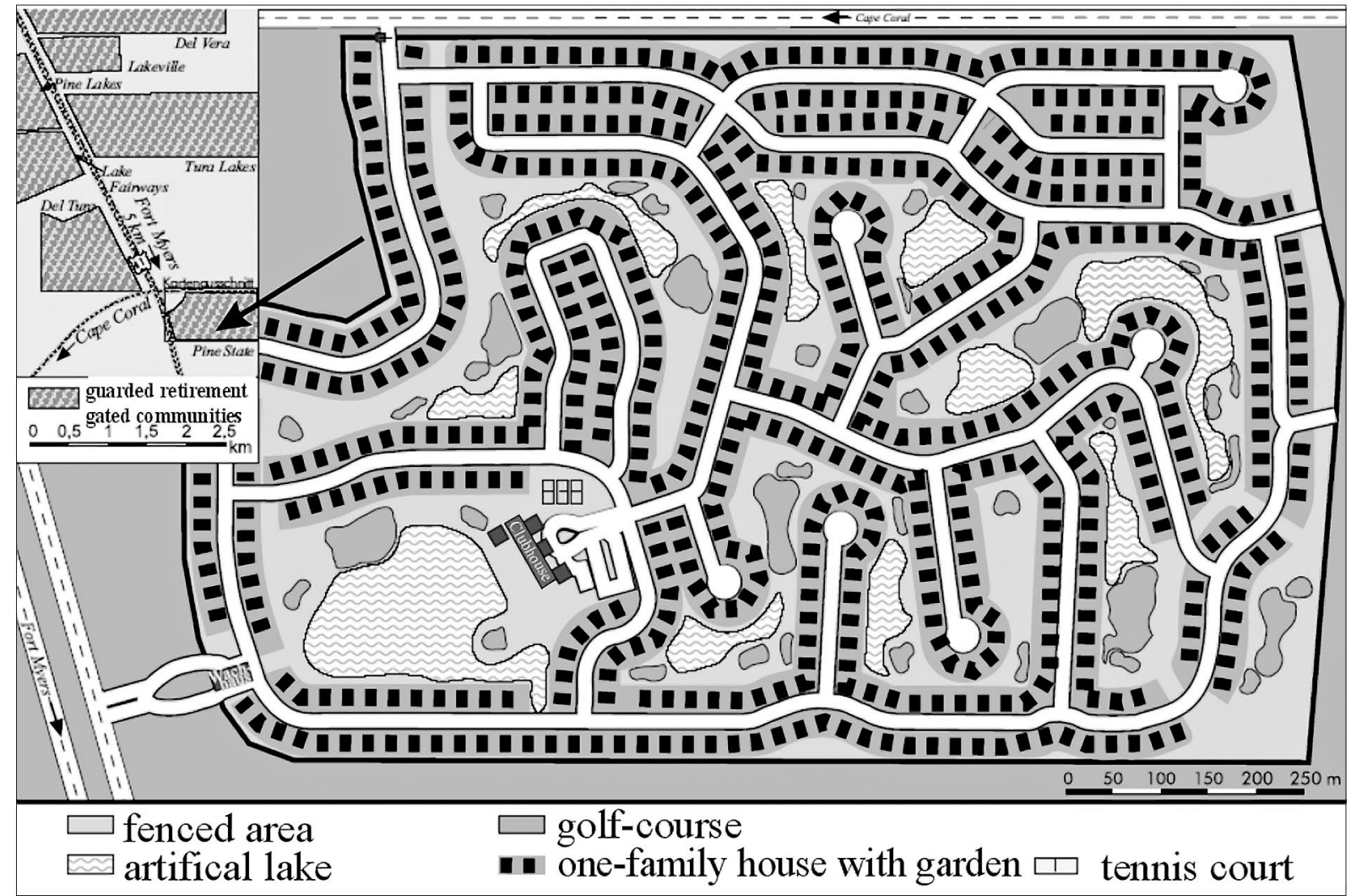

Figure 1 The morphology and features of a typical gated community located in Florida, USA (Source: Glasze, 2001, Modified by Hegedűs, 2009)

Depending on the researcher's discipline, gated com munities can be defined and categorised in many different ways and a variety of definitions are used in scientific literature. One of these definitions says that they are 'walled or fenced housing developments to which public access is restricted, often guarded using CCTV and/or security personnel, and usually characterised by legal agreements (ten ancy or leasehold) which tie the residents to a common code of conduct' (Blandy, et al., 2003, see Figures 1 \& 2) Gated communities are private developments, thus they can provide their inhabitants with exclusive local public goods ('club goods' - such as a swimming pool, fitness centre or golf course) at a higher quality and efficiency than the local government, which accounts for their global success (Webster, 2002, Glasze, 2005). Gated neighbourhoods are separated from their surroundings not only in a physical but also in a legal sense by various legal means which can sometimes fundamentally infringe the democratic rights of their residents (Blakely, Snyder, 1997). Gated communities can bring a range of relative advantages and disadvantages to their inhabitants and the neighbourhood depending on the various points of view and interests.

Gated residential developments have typical morphological features: their street pattern is often composed of loops, and cul-de-sacs. These designs have psychological significance: convoluted cul-de-sacs limit access and restrict who enters the area by acting as a deterrent to all non-residents, while also making it more difficult for criminals to escape (Blakely, Synder, 1997, Figure 1).

In many countries, gated communities are often managed by institutions of various forms called 'private neighbourhoods' which are established by the investors. As well as their own dwelling, in most cases every property owner in a gated community owns a share of the common property, such as the gardens and other facilities. This common property is overseen by elected boards of the association. Every customer has to endorse a document called 'Covenants, Conditions and Restrictions (CC\&Rs)', which details the rules and regulations for homeowners. These rules can be quite strict and are often infringed by homeowners (Blakely, Synder, 1997).

Many social, economic and cultural factors on a global, regional, and local scale are instrumental in the existence and evolution of gated neighbourhoods (Atkinson, Blandy (eds.), 2006). Besides the survival of historical antecedents, other factors contribute to the growing popularity of gat ed communities, such as economic factors (e.g. social and economical globalisation), efficient land utilisation and social factors (e.g. the fear of crime and the decline of public life of the settlements). The investors as real estate developers also play an important role in the spread of gated communities using various sophisticated ways of generating demand for their products.

There are many differences between the gated residential developments of post-socialist countries and those in more advanced capitalist countries. The first appearance of gated communities in the post-socialist countries can be dated back to the collapse of communism across the region (Smiegel, 2009). Differences in terms of income and wealth have increased significantly in the region, and these differences have resulted in a growing spatial segregation of the urban population (Kovács, 1999). Today, gated housing complexes exist from the Czech Republic (Brabec, Sýkora 2009) to Ukraine and Russia (Lentz, 2006), as well as from 


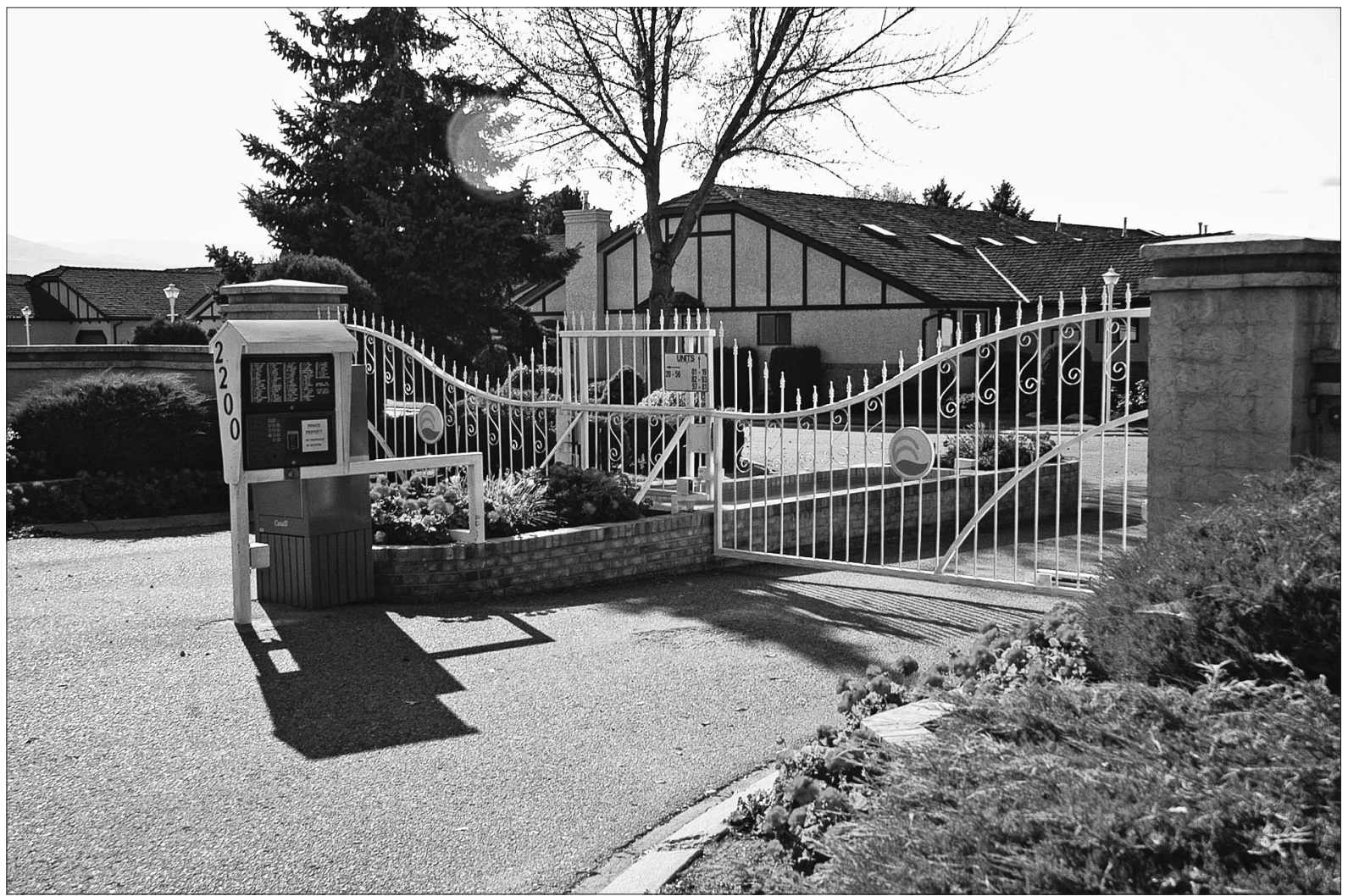

Figure 2 A typical gated community in British Columbia, Canada (Source: https://www.kelownafinehomes.com/images/dsc_1732.jpg)

Estonia to Serbia (Johnson, 2009), Romania (Negura, 2009) and Bulgaria (Stoyanov, Frantz, 2006).

Despite their increasing presence and rapid spread throughout Eastern Europe, studies of gated communities are still in their infancy in the region, and there remains a lack of comparative research with Western Europe or the United States.

Serious questions exist, such as: why are gated communities established in the region and what are the main driving forces of the process? Researchers' opinions vary greatly on the subject of which factors have greater significance, demand or supply. Some of them (e.g. Cséfalvay, 2008) take the demand-driven view, pointing out the economic advantages for residents, real estate developers and local governments, as gated communities provide services and goods that non-gated estates are not able to provide. Others, on the other hand, take a more critical point of view, saying that the demand for such developments is to an extent manufactured; by offering such flats to buyers in cunning and sometimes manipulative ways, real estate developers create an artificial demand for their product. In this way, it is said that the developers are the most important players in the establishment of gated communities, and not the potential buyers - thus, the buyers' requirements and preferences would have little influence. For this reason, this theory is referred to as the 'supply-driven' approach, which emphasises the increase in urban splintering and segregation caused by gated real estate developments (e.g. Timár, 2001, Gądecki, 2009).

During our research, our primary aim was to answer the following questions: How are the gated communities in and around the 23 most populous Hungarian cities outside of
Budapest (with the status of 'City with County Rights') diffused? What are the regional and local geographical distribution characteristics of gated neighbourhoods? And how can we categorise them?

\section{General features of gated communities in Hungary}

Studies of gated communities in Hungary have appeared only recently (e.g. Béres, 2002, Vámos, 2003, Cséfalvay, 2007, Bodnár, Molnár, 2007, Cséfalvay, 2008, Csizmady, 2008), the majority of these studies were about gated communities within Central Budapest, and only a small proportion them were concerned with the suburbs of Budapest. Beside this research, many architectural and professional real estate articles have dealt with this topic from a rather critical point of view. According to Csizmady, gated communities can be interpreted as a mere continuation of the previous housing estates built in the state socialist period in Hungary - in her opinion, there are many similarities between the two forms of residential buildings (Csizmady, 2008).

It is very important to point out that - as already mentioned - 'gated communities' in Hungary have largely very little in common with Western gated communities, such as those found in the USA. Gated communities are commonly referred to as lakópark in Hungarian (in English: 'residential park'), and even the real-estate developers in Hungary mostly use the term residential park instead of gated community in their English-language marketing materials. For the sake of consistency, we use the term 'gated community' (or its closest synonyms) in this paper. 
The construction of the first gated neighbourhood began at the very end of the 1980s in a district of Buda (the wealthier, western part of Budapest), (Béres, 2002). Later, gated housing complexes started to appear in other parts of Budapest and in its suburban areas. Considering the definition mentioned above, the gated communities of Budapest and of Hungary in general are - more or less - different from their typical western equivalents. They are not gated physically or separated legally from their surroundings. Furthermore, they are not guarded and they provide only relatively few exclusive services for their residents (Cséfalvay, 2008).

On the other hand, Hungarian gated residential developments are usually inhabited by the (upper) middle class. Their residents' motivations for moving into gated housing complexes are predominantly based on their need for welldesigned modern flats and for pleasant landscapes (Csizmady, 2008). In many countries across the world (such as in the states of Latin-America, the United States, South Africa, and Lebanon), security is a significant motivation for moving into a gated community, often due to high crime, high income inequality, political instability or ethnic tensions (Glasze, et al. (eds.), 2006). However, security is not usually the main incentive for establishing gated neighbourhoods in the post-socialist states of Europe (e.g. Smiegel, 2009), including Hungary. The importance of security is often cited as a major reason for the emergence of gated and guarded housing, but this does not seem to be the case for gated neighbourhoods in Eastern Europe. Researches suggest that it is not a particular physical danger that makes people move into closed neighbourhoods. It is rather the concept of control (such as regulations, surveillance, and codes of conduct) which makes these complexes attractive for residents. Privacy, status and lifestyle are crucial reasons for moving into gated community (Smiegel, 2009). According to research findings exceptions to this rule are scarce. For instance, Lentz mentions that in Moscow the public safety in the housing estates built during the Communist period is often insufficient (Lentz, 2006). However, we should not forget about the potential regional differences regarding this question (in the case of Hungary see below).

According to Csizmady, for residents of those gated communities in Budapest which were surveyed (sample size: 870), the reasons given for leaving their previous home were the following: The desire for a newly built flat (43.4\%); the small size of the previous flat (42.3\%); and the poor condition of the previous flat (17.8\%). The poor conditions of the previous neighbourhood ranked only eighth in the list, and public safety of the former residence ranked ninth amongst the thirteen questions concerning the reasons of moving. When asked for the reasons for moving into a gated community (18 questions given), the most important factors related to the quality of the new home, including: The desire to own a newly built flat $(87.0 \%)$; the design of the flat $(84.1 \%)$; and the wish to have a modern flat $(82.4 \%)$. The question of security did not appear as a significant factor. Secure parking only ranked in sixth place (63.5\%); a fenced off/guarded home was in seventh place (55.6\%) and public safety only appeared in twelfth position (50.4\%) (Csizmady, 2008)
As Cséfalvay puts it, on the basis of his survey of Budapest residents' opinions of living conditions in gated communities compared with their previous home (sample size:120), security considerations are important but not the most decisive factors for moving into gated neighbourhoods (Cséfalvay, 2009). While $80 \%$ of the respondents reported that the physical environment was better than that of their pre vious residence, only $61 \%$ emphasised that they felt safer in the gated residential parks than in their previous residence. The desire of the affluent upper middle class to escape from environmentally unfavourable and overcrowded areas of downtown Budapest play a much more decisive role in the decision to move into a gated community than their eager ness for self-segregation (Cséfalvay, 2009). They moved to residential parks on the edge of inner city areas because these offer a more favourable environment to live than other overcrowded parts of Budapest. The new gated communities have become a symbol of prestige and a visible manifestation of the social divide, setting the upper middle class apart from the working class (Cséfalvay, 2009).

After all, in the case of Budapest, the desire for safety only plays a minor role (Csizmady, 2008, Cséfalvay, 2009) and supposedly this is a general feature in other Hungarian settlements and regions as well. We should not forget another important factor which contributes to the occupancy of gated communities: the level of supply in a given regional or local housing market. The numbers of gated residential developments is quite significant in many countries across the world. There are some municipalities in the United States where real estate developers are only allowed to create gated developments directed by associations (McKenzie, 2006). Consequently, an indirect incentive may be the supply of housing, whereby a potential purchaser want ing to buy a new piece of prestigious residential real estate would have little option other than to buy one in a gated community.

\section{Methods and data}

There have already been several studies carried out on gated communities in Budapest (Vámos, 2003, Bodnár, Mol nár 2007, Cséfalvay, 2008, Csizmady, 2008). Although gated communities and especially gated community-like developments have rapidly spread in many Hungarian cities and towns over the last decade, little research has been carried out in these areas. For this reason, we excluded Budapest and its urban agglomeration (except the nearby town of Érd) from our research. Thus, we restricted ourselves to examining the diffusion of gated communities in and around the 23 settlements which hold the status of 'City with County Rights' (see Figures 7 \& 8). 'City with County Rights' is an administrative title assigned to settlements - excluding Budapest - with a population of between 34,000 and 205,000 in 2008. Amongst those settlements holding the title, there are regional and county administrative centres and, in some cases, other relatively populous settlements which have no county town administrative status. In addition to this, we examined the suburban areas of these 23 cities. The city's suburban area was defined by the density of 
residents as a proportion of the total number of inhabitants (above $23 \%, 2001$ ), by the increase in population (between 2000 and 2005) and by the proportion of newly built flats (above $4.5 \%$ - between 2000 and 2005). We did not examine the suburban area of Érd (see Figures 7 \& 8) because this settlement belongs to the agglomeration of Budapest - the only one among the 23 Cities with County Rights. Due to their relative proximity to Budapest, the effects of the capital's agglomeration are noticeable as far away as Tatabánya and Székesfehérvár (see Figures 7 \& 8). It is also important to note that - although in a smaller number - there are gated communities in Hungarian settlements which were not covered by this research.

Our assumption was that gated neighbourhoods can be interpreted as a phenomenon of the globalisation process. We assume that the effects of globalisation appear gradually at different levels of the settlement hierarchy in such a way that they are more frequent and intensive at the upper levels, while they are more infrequent at the lower levels (see Boros, et al., 2006). Gated housing complexes as modern global innovations emerge principally in a way that can be described with the help of the hierarchical diffusion model and neighbourhood diffusion model (Rechnitzer, 1993). This model can be applied not only in the case of Budapest but also across the whole country. Our further hypothesis was that gated communities are more frequent in the economically well-developed areas of Hungary (e.g. in the Ag- glomeration of Budapest or Northwest-Transdanubia, see Figure 3) due to factors such as high personal income and purchasing power. In fact, the value of the personal income tax base measured at the settlements level (NUTS 5) in Hungary does not represent all of the income of tax-paying residents, nevertheless the figures may be interpreted as an approximate indicator of wealth. We are inclined to think that the development of gated communities is influenced not only by geographical factors but also by the policies of local governments and by the influence of local nongovernmental organisations.

Considering the analysis of spatial distribution, the Hungarian Central Statistical Office (HCSO) has already created a definition of a gated community. However, the HCSO has only used it as a statistical category in its publications since 2004. According to the HCSO, a gated community is 'a building complex composed of a number of flats, built mostly with physical barriers as a closed residential area in a uniform architectural style on one piece of land registered under the same topographical number' [2]. However, it often happens that the statistics of the HCSO do not cover all of the gated communities [2]. Thus, as we were without an adequate spatially detailed database, we collected and collated data about gated housing complexes. We mostly used internet data sources (such as [1]). Advertising on the internet is one of the most important marketing tools for real estate developers and a substantial amount of information

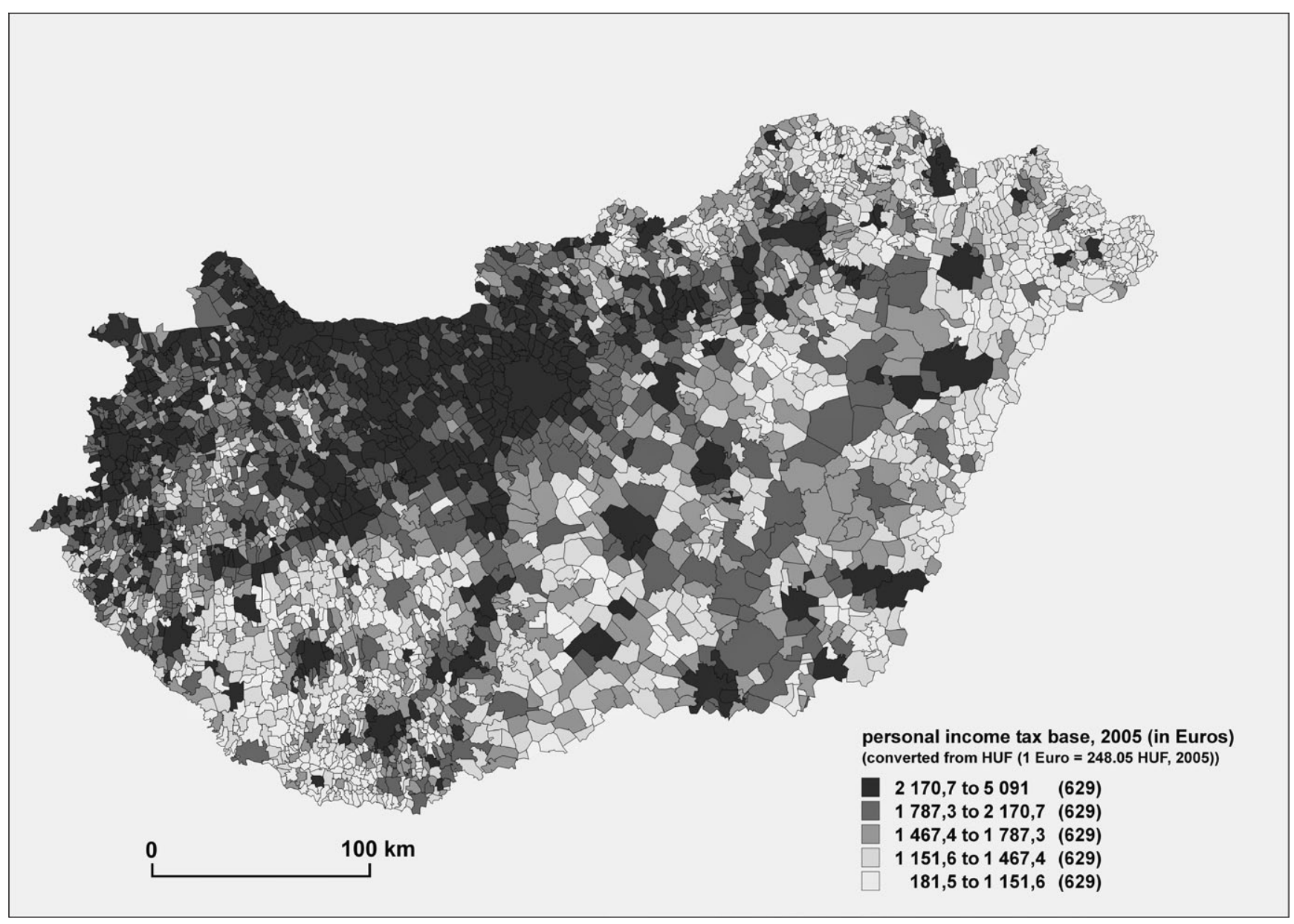

Figure 3 Spatial differences in the personal income tax base per capita in Hungarian municipalities in 2005 (Source: HCSO T-STAR 2005, edited by Hegedűs, 2009) 


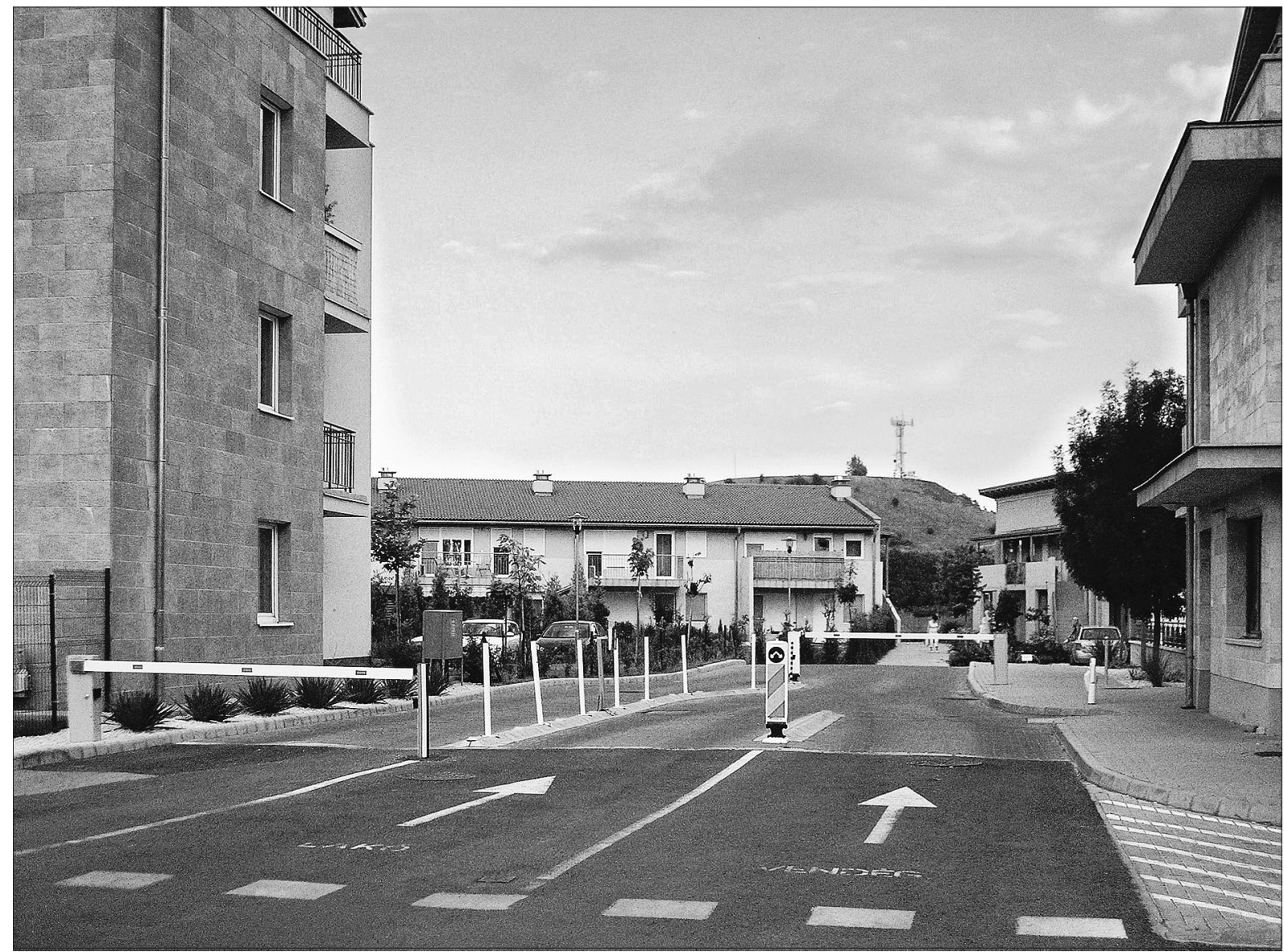

Figure 4 A western-like Type 1 gated community in Kecskemét (Source: Hegedűs, G., 2009)

was obtained from resources such as these. In spite of its limitations, this method of data collection is well known and widely used in scientific literature on gated communities (e.g. Maxwell, 2004, Grant, 2006, Cséfalvay, 2008, Csizmady, 2008). We supplemented our internet data with telephone interviews with representatives of local governments and real estate developers. We analysed the spatial distribution of gated housing complexes using satellite images and aerial photographs with the help of Google Earth software.

As mentioned previously, the term 'gated community' is a generic term applied to both its functions (e.g. physical segregation and services) and its morphology (e.g. architec-

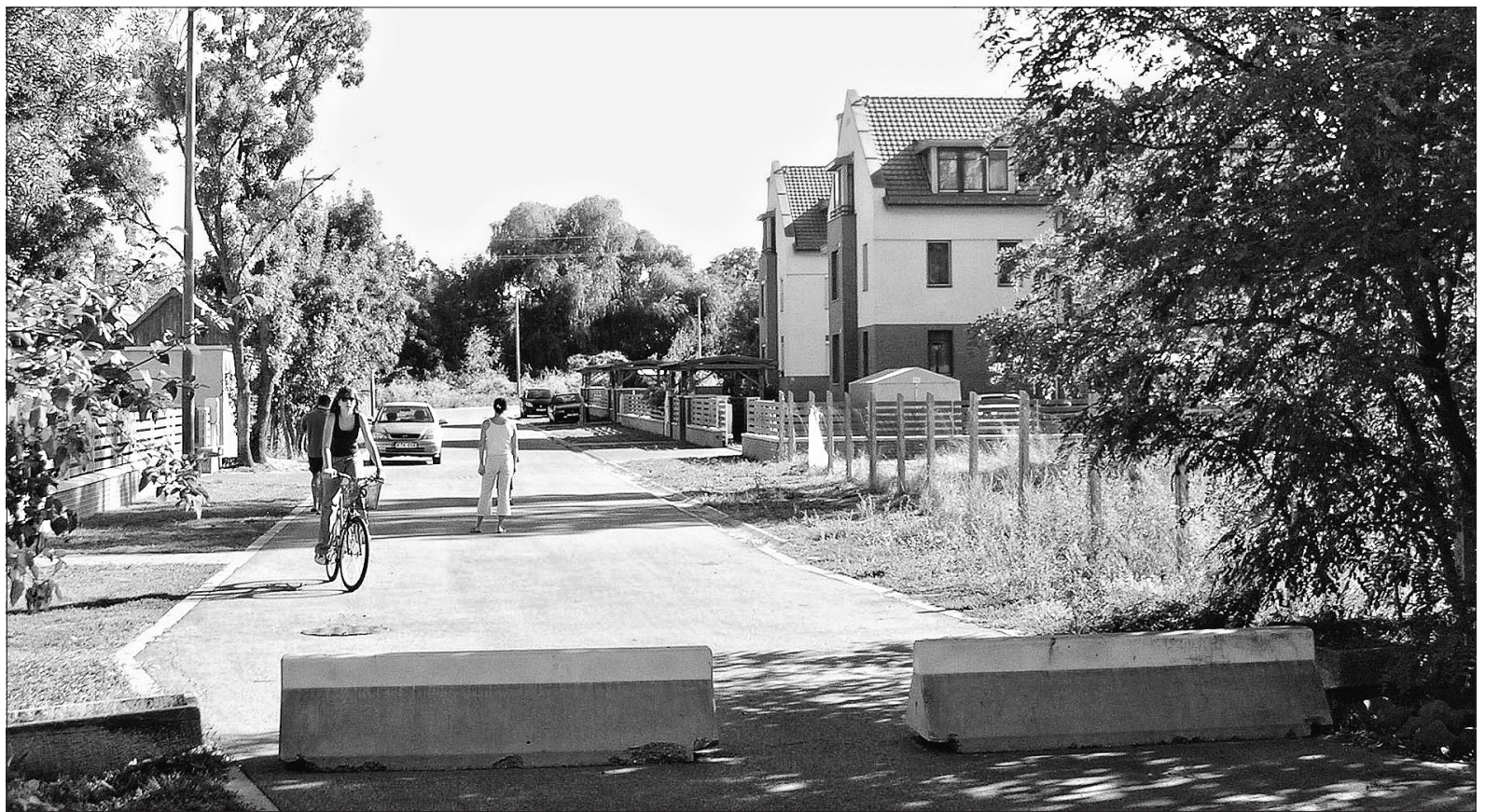

Figure 5 A Type 2 gated community in Hódmezővásárhely (with physical barriers but without services) (Source: Hegedűs, G., 2008) 


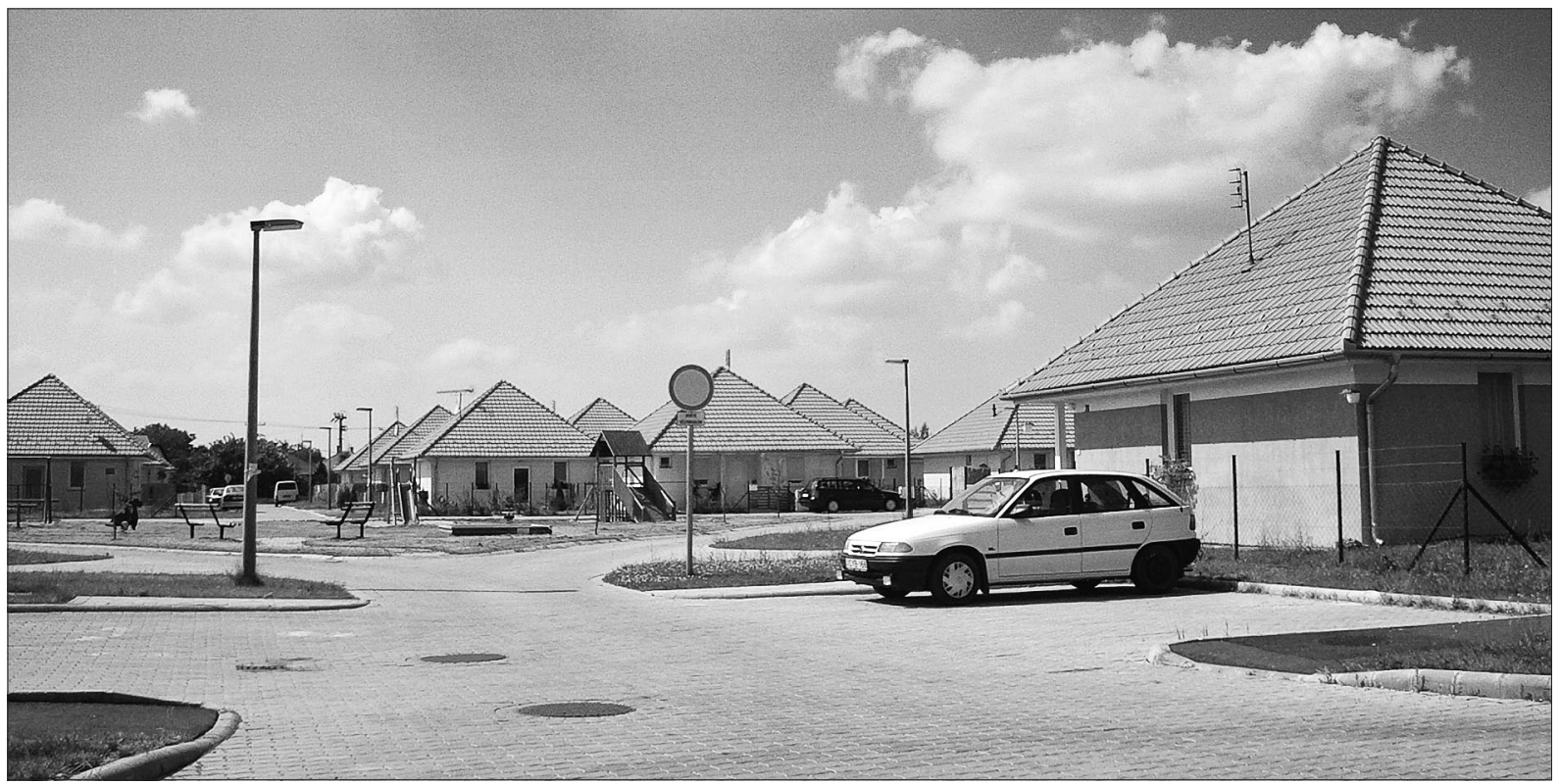

Figure 6 A Type 3 gated community in Békéscsaba (without gates or security) (Source: Hegedűs, G. 2007)

tural character). We tried to classify gated communities in this study only by their functions, and we scarcely mention their morphology. We used a simplified definition in our study that can be adapted relatively well to the Hungarian situation, which was the following: a gated community is a set of buildings which comprises at least 20 flats. It is fenced/walled from its environment (function of physical separation), and it delivers some kind of collectively consumed services (e.g. maintained green spaces). It also includes collectively used amenities for its inhabitants such as playgrounds, swimming pools, etc. (function of services).

There were some real estate constructions that comprised fewer than 20 flats. We made a weighting when we applied this size-limit by excluding smaller projects during the course of our study. We examined all kinds of real estate developments that define themselves as 'gated communities' or in a similar such way (such as 'residential garden' or 'residential grove', etc.). Those real estate developments which closely fitted our definition were named 'gated communities with complete functions' (hereafter 'Type 1', Figure 4). Those projects which were physically separated from their surroundings without delivering any additional services to their inhabitants were termed as 'gated communities with incomplete functions' (hereafter 'Type 2', Figure 5). Developments lacking any physically separation but delivering services were designated as 'pseudo-gated communities' (hereafter 'Type 3', Figure 6). We consider the analysis of the final group to also be of great importance.

In some cases, it was hard to categorise a particular real estate development due to a lack of information. While many gated housing complexes are constructed in stages, it sometimes happened that we could not get information about the state of the development or the number of completed flats. For this reason, we not only collected data about completed projects, but also about those under construction and also - in very few cases - those in the planning stage. Nevertheless, the number of developments which did not have suitable data was so low that we consider our data to be reliable.

\section{Geographical distribution of gated communities in Hungary}

While gathering data, it became obvious that in many cases even the real estate developers misuse the term 'gated community'. The expression is applied as a buzzword to describe many real estate developments which, in fact, have no fencing or services. That is why the proportion of 'pseudo-gated communities' (Type 3) is the highest of the three settlement types (Table 1). However, interestingly, there were some real estate projects that to a certain degree fitted our definition of the term gated community, but which were not referred to as such (see one example of this in Figure 5). Therefore, there seems to be inconsistencies between the naming and the actual functional and morphological features of gated communities.

Real estate developers, who are mainly foreign-owned, play an important role with their marketing strategies using resources such as internet websites and billboards. Similar means of advertising is also employed for developments in the agglomeration zone of Budapest (Bodnár, Molnár, 2007, Cséfalvay, 2008, Csizmady, 2008). Their aim is to attract potential homebuyers, and to this end they attempt to woo customers with the promise of a 'better life' or the opportunity to boost one's social status.

Our hypotheses that the spread of gated housing complexes is determined by settlement hierarchy and socialeconomical development (purchase power) was only partly supported by the research. Approximately half of the devel-

Table 1 The number of gated communities and gated community dwellings by type

\begin{tabular}{|l|c|c|c|c|}
\hline & Type 1 & Type 2 & Type 3 & Total \\
\hline $\begin{array}{l}\text { Number of gated } \\
\text { communities }\end{array}$ & $\begin{array}{c}41 \\
(27.2 \%)\end{array}$ & $\begin{array}{c}33 \\
(21.2 \%)\end{array}$ & $\begin{array}{c}77 \\
(51.0 \%)\end{array}$ & 151 \\
\hline $\begin{array}{l}\text { Number of gated } \\
\text { community } \\
\text { dwellings }\end{array}$ & $\begin{array}{c}5869 \\
(28.4 \%)\end{array}$ & $\begin{array}{c}2843 \\
(13.8 \%)\end{array}$ & $\begin{array}{c}11852 \\
(57.6 \%)\end{array}$ & 20564 \\
\hline
\end{tabular}

(Source: Hegedús, 2009) 


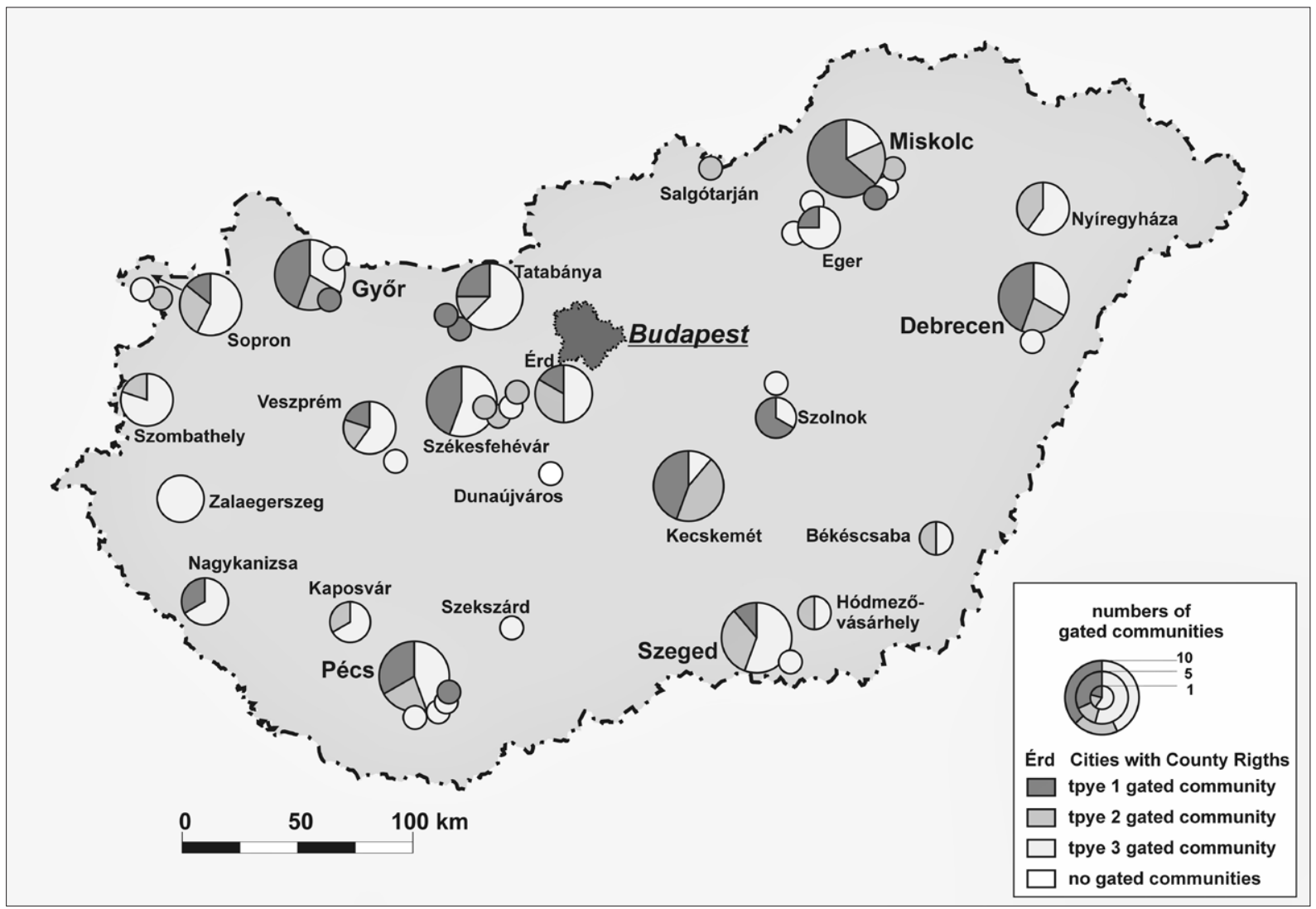

Figure 7 The number of gated communities in the 23 Cities with County Rights (labelled) and their suburban areas (Source: Hegedűs, 2009)

opments which defined themselves as gated communities cannot be considered as a real gated community in terms of the functions they provide (Type 3, Table 1, Figure 7). Many of the Cities with County Rights contain no Type 1 gated communities (even in the relatively populous Nyíregyháza, Szombathely and Kaposvár). In some cities (e.g. Szekszárd) no Type 2 gated communities were registered. Nor is there a development defined as a gated community in the city of Dunaújváros or its suburban area (Figure 7, Figure 8).

The highest number of gated housing complexes was found to be in Miskolc (at the centre of the Northern Hungary NUTS 2. region, Table 2). The number and density of the Type 1 gated communities is the highest here, which is remarkable because in Miskolc - compared with other regional centres - the purchasing power is low and it is one of the most disadvantaged regions in Hungary (Figure 3, Figure 7, Figure 8). Public safety cannot be regarded as greatly favourable in the city, and the proportion of disadvantaged residents (e.g. Roma people) is relatively high compared with the rest of the country. For this reason, it is important

Table 2 Those cities with the highest proportion of Type 1 gated communities

\begin{tabular}{|l|l|l|l|l|}
\hline $\begin{array}{l}\text { Cities with } \\
\text { County Rights }\end{array}$ & Type 1 & Type 2 & Type 3 & Total \\
\hline 1. Miskolc & $7(63.6 \%)$ & $2(18.2 \%)$ & $2(18.2 \%)$ & 9 \\
\hline 2. Kecskemét & $4(44.4 \%)$ & $4(44.4 \%)$ & $1(11.2 \%)$ & 9 \\
\hline 3. Győr & $4(44,4 \%)$ & $2(22.2 \%)$ & $3(33.4 \%)$ & 9 \\
\hline 3. Debrecen & $4(44,4 \%)$ & $2(22.2 \%)$ & $3(33.4 \%)$ & 9 \\
\hline
\end{tabular}

(Source: Hegedüs, 2009) to mention that that the issue of safety may play a more significant role in Miskolc than in many other cities in Hungary in the decision of local residents to move into gated communities. Kecskemét is second in the list, with Györ and Debrecen in joint third position. It is interesting that there are few gated communities in Szeged (the centre of Southern Great Plain NUTS 2 region) and the number and proportion of Type 1 developments is still quite low.

The highest number of gated housing complexes proportional to the resident population was found to be in Kecskemét, Miskolc and Székesfehérvár. Most of the gated communities built in the suburban areas can be found in Transdanubia (e.g. around Tatabánya, Székesfehérvár and Pécs). Miskolc is also worth mentioning for its suburban gated communities, as it is here where the highest number of gated communities east of the Danube can be found.

Analysing the number of gated community dwellings, significant differences are also revealed across the country (Figure 8).

On the basis of our research, the 151 gated communities which we analysed comprised 20564 dwellings in total (Table 1). As can be seen, Type 3 developments make up the highest number of dwellings when compared with Type 1 and Type 2. The highest number of dwellings (finished and under construction) was found to be in Szeged (Table 3). This high number can be accounted for by several closely built gated communities (Type 3) in the inner city of Szeged. On the outskirts of the city, several new developments (Type 3, family house types) are under construction. The proportion of Type 1 developments is low, which contrasts with Debrecen where the number of dwellings is the 


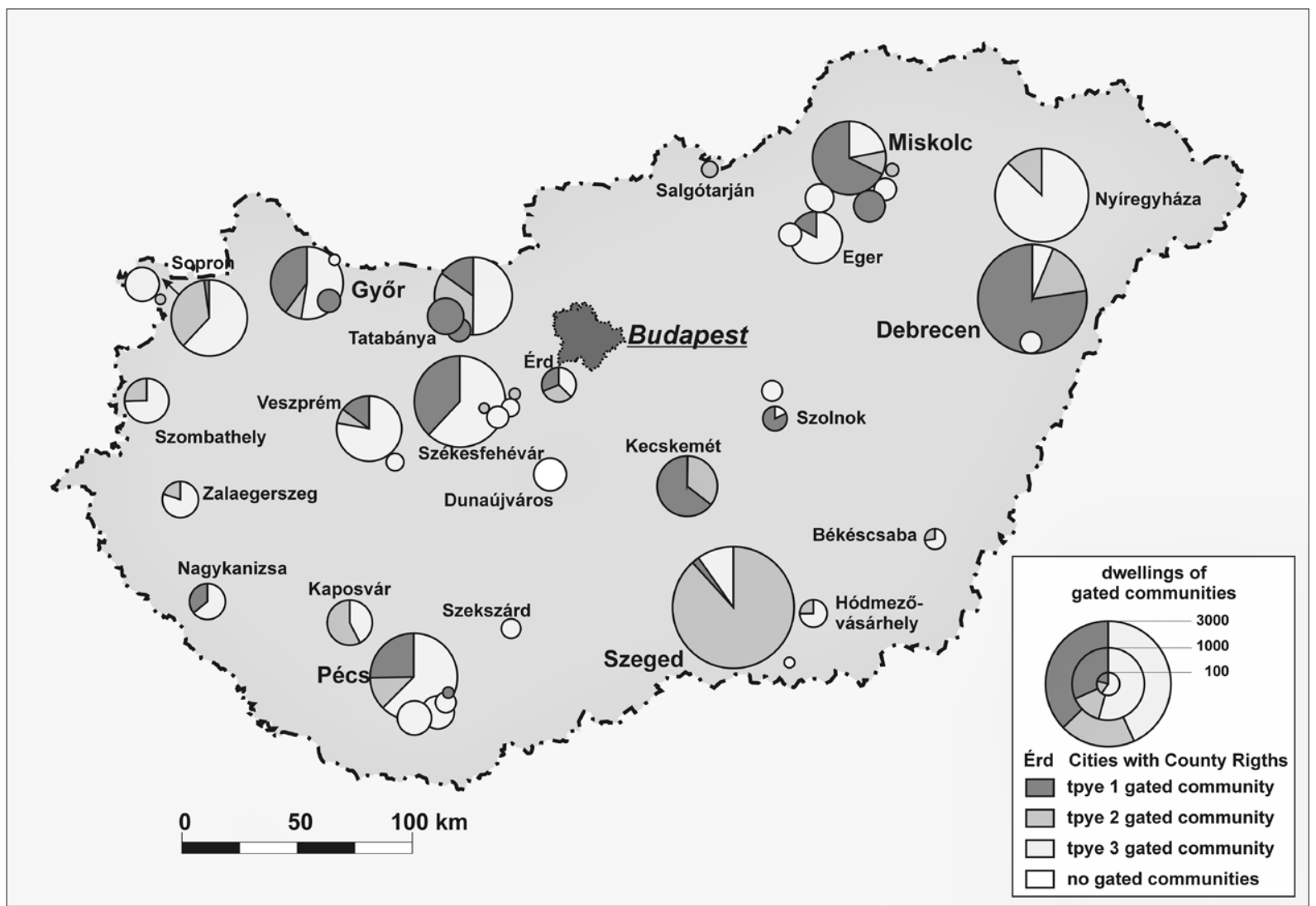

Figure 8 The number of gated-community dwellings in the 23 Cities with County Rights (labelled) and in their suburban areas (Source: Hegedűs, 2009)

second highest among the 23 cities, and where the greatest number of dwellings were found to be Type 1 gated communities. Miskolc ranks only 8 th, as there are many smallersized gated housing complexes (belonging mainly to Type 1) in the city.

The portion of Type 1 gated commnity dwellings is the highest in Szolnok, followed by Debrecen and then Miskolc. If we compare the number of dwellings with the resident population of the Cites with County Rights, we find that the highest proportion of Type 1 dwellings are to be found in Debrecen, Székesfehérvár and Miskolc.

Not only are the spatial patterns of gated communities worth analysing, but also spatial distribution inside the cities is of interest. At this second subordinated level, specific patterns in the location of gated housing complexes can be observed. Gated communities often appear in clusters that are concentrated in the favourable areas of a city. For instance, in Kecskemét, gated communities are concentrated near the local arboretum - a pleasant area with many

Table 3 Those cities with the highest number of gatedcommunity dwellings

\begin{tabular}{|l|c|c|c|l|}
\hline $\begin{array}{l}\text { Cities with } \\
\text { County Rights }\end{array}$ & Type 1 & Type 2 & Type 3 & Total \\
\hline 1. Szeged & $\begin{array}{c}275 \\
(9.8 \%)\end{array}$ & $\begin{array}{c}56 \\
(2.0 \%)\end{array}$ & $\begin{array}{c}2487 \\
(88.3 \%)\end{array}$ & 2818 \\
\hline 2. Debrecen & $\begin{array}{c}1754 \\
(77.4 \%)\end{array}$ & $\begin{array}{c}369 \\
(16.3 \%)\end{array}$ & $\begin{array}{c}142 \\
(6.3 \%)\end{array}$ & 2265 \\
\hline 3. Nyíregyháza & $\begin{array}{c}0 \\
(0 \%)\end{array}$ & $\begin{array}{c}214 \\
(12.9 \%)\end{array}$ & $\begin{array}{c}1450 \\
(87.1 \%)\end{array}$ & 1664 \\
\hline
\end{tabular}

(Source: Hegedüs, 2009) green spaces; in Miskolc they are to be found on a hill, providing a panorama; and in Györ they are situated along the banks of Danube, a desirable riverside location. The same factors, along with others not yet mentioned, determine the location of gated communities in the agglomeration of $\mathrm{Bu}-$ dapest.

In the inner zones of the cities which were analysed, it is the 'brown field gated communities', established in formerly built-up areas, which are usually the most numerous. These constructions sometimes result from a significant change in the function of an area, such as the demolition of old cemeteries in Szeged and army barracks in Nyíregyháza. 'Green field gated communities', constructed on land where buildings did not formerly exist and typically featuring generous open spaces between buildings, are much more common on the outskirts of cities, such as in Pécs and Szeged. It appears that there are more 'brown field gated communities' in those cities where heavy-industry has collapsed on a large scale, bringing about a more dramatic change in the spatial function of large areas of the city.

Although we did not directly survey the residents about their motives for moving into gated communities or gated-community developments, we can come to some indirect conclusions. Based on our information, the main triggers for moving into a gated community were the need for a well-designed modern flat and pleasant surroundings, but not primarily the issue of security, as was also the case with Budapest (Csizmady, 2008). There seem to only be a few exceptions to this trend amongst the cities we analysed (e.g. Miskolc). The proportion of real gated or residential developments was often quite high in the local housing sup- 


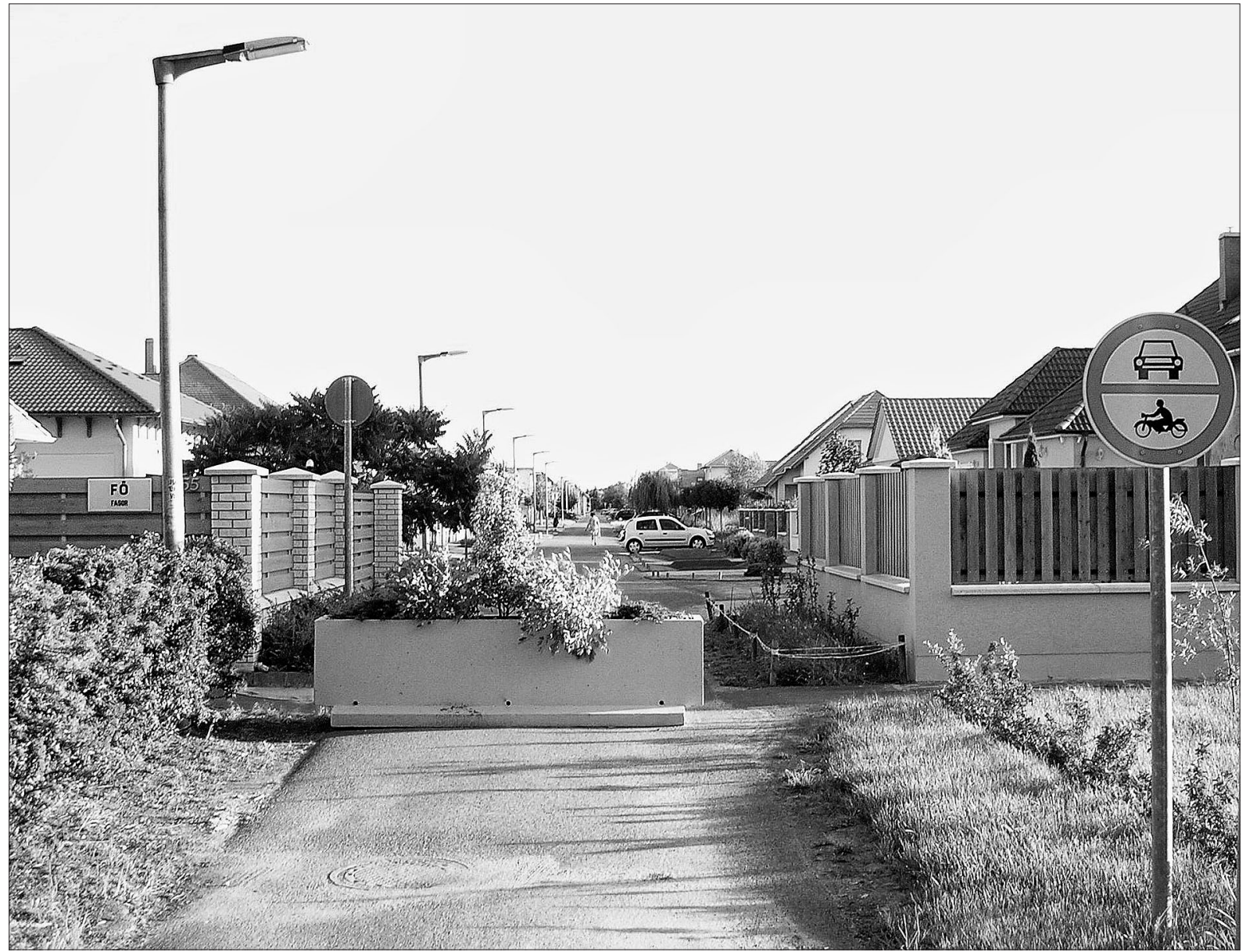

Figure 9 A gated community in Szeged (Source: Hegedűs, G. 2007)

ply markets (Table $2 \& 3$, Figure $7 \& 8$ ). In the search for a decent neighbourhood, without having real alternatives, some home buyer may have no other choice but to move into a gated community. This is compounded by the fact that real estate developers often carry out intensive marketing activity, promising potential buyers a 'better life', and a strong and stable investment. They can utilise and commodify the favourable natural and cultural characteristics mentioned above (such as panoramas and riverside locations). These supply-driven incentives are very effective in attracting buyers to gated communities. A demand-driven factor could be that in some Cities with County rights (such as in North-Transdanubia) the economy is developing rela tively fast, which attracts workers from the underdeveloped distant regions of Hungary who are aiming at buying real estate locally. In some border cities, such as in Györ and Sopron, the citizens of adjoining EU-member countries, in cluding Austria and Slovakia, also buy homes and move into gated communities, as real estate prices are often significantly lower than in their own country.

During the research, numerous effects caused by gated housing complexes were observed. For a city, the advantages of gated communities include: brown field revitalisation, the increase in economic value, and the increase in the prestige of an area. An advantage for an individual would be the more efficient provision of higher quality club goods compared to the city's public services. However, the disadvantages of gated communities for a city are also numerous since they sometimes endanger natural resourc- es, such as forests and groves - as was the case in Debrecen, Szeged and Tatabánya. Supposedly, the gated communities of the 23 cities are also inhabited by the (upper) middle classes who use public transport, as well. Public transport is not always satisfactory in the vicinity of gated communities (notably in the case of those built on the outskirts, such as in Szeged and Szombathely). Even in more central areas of cities where gated communities are built, it sometimes happens that insufficient public transportation is provided (such as a gated neighbourhood in Szeged), which can lead to complaints against the local government.

Real estate developers are generally interested in maximising the returns they make on their investments. Presumably, this is the reason why gated housing complexes with multi-storey buildings are built even on the outskirts of cities - and in other areas where the surrounding buildings are lower in height. For this reason, the inhabitants living in the area surrounding the site of a planned gated community often oppose its development, because they are afraid of, for instance, increased traffic and environmental pollution (Csizmady, 2008, Csizmady, Csanády, 2009). Also, in the case of real estate developments which are densely planned, they are concerned that the finished buildings will not suit the functional-morphological character of the area. Local non-governmental organisations are increasingly opposed to the building of such projects, sometimes accusing the local municipalities of being partial towards real-estate developers' interests and being biased against the interests of existing local residents. In some cities, such as Tatabánya, 
local referendums were held to determine whether or not to permit the building of gated communities. In Tatabánya, the mentioned referendum resulted in a victory for proponents of the development.

However, it is interesting that some other problems which gated communities can bring are generally not seen as a serious issue for the local residents. Such problems may include the exclusion of non-members or the increasing proportion of private and pseudo-private areas by establishing gated neighbourhoods. It might be regarded as somewhat peculiar that even the inhabitants of some Type 3 gated communities which were examined sometimes erected barriers at several entrance points to their territory to reduce transit traffic (such as in Szeged, Figure 9). Other forms of social exclusion seem not to raise problems in some cases in Hungary, either; in one study carried out in Szeged, the exclusion of (mostly homeless) beggars from certain residential areas of the city was supported by a significant part of the city's population (Boros, 2007).

\section{Conclusion}

Gated communities are originally closed and guarded sets of residential buildings providing a variety of services to their residents. They were first built in the United States in large numbers. They can be interpreted as a global residential and recreational form of consumption, and they have many functional and morphological variations. Gated real estate developments appeared in Hungary at the very end of the 1980 os, initially in Budapest.

In our research, we examined their spatial distribution in the 23 Cities with County Rights and their suburban areas, and tried to categorise them in a functional way. Our results partially contradicted our hypothesis that the spread of gated communities is determined by the position of the given settlement in a settlement hierarchy (by the size of the population) and by the level of regional and local economic development (by purchasing power). The concerns about security, as opposed to the demand for modern flats and pleasant landscapes, seem not to be primary motivating factor for moving into a gated housing complex, except perhaps in some cities, such as Miskolc. Gated communities and similar developments can be found, not only in the agglomeration of Budapest, but in all the settlements examined as part of this research and in other places as well. Real estate developers started to construct them in settlements located outside the agglomeration of Budapest a decade ago. Of those examined, the proportion of real functional gated communities was low. The number and location of gated communities within a settlement is determined by several geographical factors as well as local governments' policies. Gated neighbourhoods may often be situated in clusters in such areas where the previously mentioned factors are favourable for the developers.

Further quantitative and qualitative studies are needed to analyse the factors influencing the spatial distribution of gated real estate developments in more detail. The number of gated communities in the settlements which were examined will presumably increase in the future since they can produce higher quality club goods than those provided by the local municipalities. However, we should take into consideration the problems generated by them such as environmental hazards and partial or complete exclusion of outsiders, etc. Further research could be done into the connection between levels of poverty and the relative numbers of fully-secured gated housing complexes which aim to segregate the poor from the middle classes. The location and morphology of gated communities as well as the social characteristics of their inhabitants and characteristics of those living in their adjoining areas should also be studied in more detail. Furthermore, it would be essential to analyse the roles, interests and activities of local governments, real estate developers and the local society (such as civil institutions) in the process of establishing gated neighbourhoods. These questions have already been examined, principally in relation to the suburbanisation process in Hungary (see Timár, 2001).

\section{References}

Atkinson, R., Blandy, S. (eds.) 2006. Gated communities. Routledge, London-New York, 242 pp.

Béres, J. 2002. The rising segments of housing market: the spreading of gated communities in Budapest. Master Thesis, Eötvös Lóránd University, Budapest, 63 pp. (in Hungarian)

Blakely, E. J., Snyder, M.G. 1997. Fortress America. Gated communities in the United States. Brookings Institution Press, Washington, D.C., 209 pp.

Blandy, S., Lister, D., Atkinson, R., Flint, J. 2003. Gated communities: A Systematic Review of the Research Evidence. University of Bristol - University of Glasgow. 63 pp.

Bodnár, J., Molnár, V. 2007. Reconfiguring private and public: state, capital and new planned communities in Berlin and Budapest. $4^{\text {th }}$ International Conference of the research network Private urban governance \& gated communities, Université Paris, Panthéon-Sorbonne, 2007. CD-ROM

Boros, L., Hegedüs, G., Pál, V. 2006. Effects of globalisation on cities of the Great Hungarian Plain - the transition of urban structure and cityscape. Hungarian Academy of Sciences, 3rd Hungarian Geographical Conference, Budapest, CD-ROM (in Hungarian)

Boros, L. 2007. ...But some are less equal - spatial exclusion in Szeged. In: Kovács, Cs. (ed.) From villages to cyberspace. University of Szeged, Department of Economic and Human Geography, Szeged. pp. 151-16o.

Brabec, T., Sýkora, L. 2009. Gated Communities in Prague. In: Smiegel, C. (ed.) 2009: Forum IfL - Gated and Guarded Housing in Eastern Europe, Leibniz-Institut für Länderkunde, Leipzig, pp. 83-90.

Cséfalvay, Z. 2007. New Segregation with New Conflicts: Demystifying Gated Communities in Budapest. Paper presented at the 4 th International Conference of the research network Private urban governance \& gated communities held at the Université Paris 1 PanthéonSorbonne, 5- 8 June 2007. CD-ROM 
Cséfalvay, Z. 2008. Gates, walls, barriers: the world of gated communities. Gondolat-Marina Part, Budapest, 300 pp. (in Hungarian)

Cséfalvay, Z. 2009. Demystifying Gated Communities in Budapest In: Smiegel, C. (ed.) 2009: Forum IfL - Gated and Guarded Housing in Eastern Europe, Leibniz-Institut für Länderkunde, Leipzig, pp. 35-47.

Csizmady, A. 2008. From housing estates to gated communities. Új Mandátum, Budapest, 321 pp. (in Hungarian)

Csizmady, A., Csanádi, G. 2009. From housing estates to gated communities. In: Smiegel, C. (ed.) 2009: Forum IfL - Gated and Guarded Housing in Eastern Europe, Leibniz-Institut für Länderkunde, Leipzig, pp. 9-19.

Gądecki, J. 2009. New social milieus - gated communities in Polish urban landscape. In: Smiegel, C. (ed.) 2009: Forum IfL - Gated and Guarded Housing in Eastern Europe, Leibniz-Institut für Länderkunde, Leipzig, pp. 2934.

Glasze, G. 2001. Privatising public spaces? Shopping centres, Business Improvement Districts and Gated Communities. In: Berichte zur deutschen Landeskunde, 2-3., pp. 160-177. (in German)

Glasze, G. 2005. Some Reflections on the Economic and Political Organisation of Private Neighbourhoods. Housing Studies, 2, 221-233.

Glasze, G., Webster, C. - Frantz, K. (eds.) 2006. Private communities: Global and Local Perspectives. Routledge, London-New York, $242 \mathrm{pp}$.

Grant, J. 2006. Planning Responses to Gated Communities in Canada. In: Atkinson, R. - Blandy, S. (eds.): Gated communities. Routledge Studies in Human Geography, Routledge, London - New York, pp. 84-96.

Johnson, C. 2009. The status of gates in Belgrade: notes on style and markets. In: Smiegel, C. (ed.) 2009: Forum IfL - Gated and Guarded Housing in Eastern Europe, Leibniz-Institut für Länderkunde, Leipzig, pp. 21-28.

Kovács, Z. 1999. Cities from state-socialism to global capitalism: an introduction. Geojournal 1, 1-6.

Lentz, S. 2006. More gates, less community? Guarded housing in Russia. In: Glasze, G. - Webster, C. - Frantz, K. (eds.) 2006. Private communities: Global and Local Perspectives. Routledge, London-New York, pp. 206- 221.
Maxwell, K. D. 2004. Gated Communities: Selling the Good Life. Paper presented at Canadian Institute of Planners (CIP) Conference, Toronto, 11-14 $4^{\text {th }}$ July 2004 [http://gated.architectureandplanning.dal.ca/Gated\%2ocommunities\%20-\%2oselling\%2othe\%2ogood\%2olife.pdf, accessed 21 $1^{\text {st }}$ August 2009]

McKenzie, E. 2006. Emerging trends in state regulation of private communities in the U.S. Geojournal, 1-2, 89-102.

Negura, O. 2009. Residential ensembles in "hypermodern times". A case study of their aspirations in Bucharest. In: Smiegel, C. (ed.) 2009: Forum IfL - Gated and Guarded Housing in Eastern Europe, Leibniz-Institut für Länderkunde, Leipzig, pp. 59-67.

Rechnitzer, J. 1993. Disintegration or catching up. Innovations shaping the spatial structure. Centre for Regional Studies of Hungarian Academy of Sciences, Győr, 208 pp. (in Hungarian)

Smiegel, C. 2009. Preface and Introduction. Forum IfL Gated and Guarded Housing in Eastern Europe, Leibniz-Institut für Länderkunde, Leipzig, pp. 5-8.

Smiegel, C. (ed.) 2009. Forum IfL - Gated and Guarded Housing in Eastern Europe, Leibniz-Institut für Länderkunde, Leipzig, 102. pp.

Stoyanov, P., Frantz, K. 2006. Gated communities in Bulgaria: interpreting a new trend in post-communist urban development. Geojournal. 1-2, 57-63.

Timár, J. 2001. Nevertheless, in whose interest? Suburbanisation in the capitalising Hungary. 1st Hungarian Geographical Conference, Szeged, CD-ROM (in Hungarian)

Vámos, D. 2003. Consuming and home-building: structur al changes of home-building after the system change in Hungary. Part 1 and 2. (in Hungarian)[http://arch.eptort.bme.hu/18/18vamosd.html, http://arch.eptort.bme. hu/21/21vamos.html, accessed 21 ${ }^{\text {st }}$ August 2009]

Webster, C. 2002. Property rights and the public realm: gates, green belts and Gemeinschaft. Environment and Planning B, 3, 397-412.

[1] www.lakopark.lap.hu

[2] http://www.napi.hu/default.asp?cCenter=article. asp\&placein=hirkereso_cimoldal\%2o\&nID =331653 (Statistics show a fall. What is wrong with gated communities?) (in Hungarian, accessed $21^{\text {st }}$ August 2009) 